\title{
Characterization of a Virus Infecting Lisianthus
}

C. C. Chen, Department of Plant Protection, Taichung District Agricultural Improvement Station, Changhua 515, Taiwan; Y. K. Chen, Department of Plant Pathology, National Chung-Hsing University, Taichung 402, Taiwan; and H. T. Hsu, Floral and Nursery Plants Research Unit, U.S. Department of Agriculture, Beltsville Agricultural Research Center, Beltsville, MD 20705-2350

\begin{abstract}
Chen, C. C., Chen, Y. K., and Hsu, H. T. 2000. Characterization of a virus infecting lisianthus. Plant Dis. 84:506-509.

A virus was isolated in Taiwan from imported lisianthus (Eustoma russellianum) plants bearing viruslike symptoms and was biologically, physically, and serologically characterized. Purified virions are isometric and measure 32 to $33 \mathrm{~nm}$ in diameter. The virus from Taiwan is morphologically similar to and serologically related to Lisianthus necrosis necrovirus (LNV) reported in Japan. This lisianthus virus does not have the same host range that was reported for LNV from Japan, but inoculation studies show that it is a strain of LNV.
\end{abstract}

Additional keywords: electron microscopy, ELISA, immunogold labeling, ultrastructure

Lisianthus (Eustoma russellianum (Don.) Griseb) is a herbaceous plant cultivated for flower production. It is an important ornamental crop in Japan, Israel, Europe, and the United States $(1,9,12)$. The species has become popular as a cut flower in Japan and Korea. Year-round production in the United States has been suggested (21). This species is also gaining popularity in Taiwan, where it is usually planted in the fall and harvested the following spring. In March 1995, several unnamed imported cultivars of lisianthus plants showing viral symptoms were discovered in Yung-jing County of Changhua Prefecture. Symptoms observed included severe necrotic spots on leaves and stems, colored stripes on petioles, and color breaks and malformation of flowers. Electron microscope examination of crude sap extracted from leaves of diseased lisianthus revealed the presence of isometric particles. They measured 32 to $33 \mathrm{~nm}$ in diameter in negatively stained preparations.

Corresponding author: H. T. Hsu

E-mail: hhsu@asrr.arsusda.gov

Mention of a trademark or proprietary product does not constitute a guarantee or warranty of the product by the U.S. Department of Agriculture, and does not imply its approval to the exclusion of other products that may also be suitable.

Accepted for publication 1 February 2000.

Publication no. D-2000-0313-02R

This article is in the public domain and not copyrightable. It may be freely reprinted with customary crediting of the source. The American Phytopathological Society, 2000.
At least 10 distinct viruses have been reported to infect lisianthus. These include Bean yellow mosaic virus (BYMV, genus Potyvirus) $(2,9,15)$, Broad bean wilt virus (BBWV, genus Fabavirus) (12), Cucumber mosaic virus (CMV, genus Cucumovirus) $(9,12,20)$, Lisianthus necrosis virus (LNV, genus Necrovirus) $(11,12)$, Lisianthus line pattern virus (LLPV, genus Ilarvirus) (17), Tobacco mosaic virus (TMV, genus Tobamovirus) (9), Tomato mosaic virus (ToMV, genus Tobamovirus) (16), Tomato spotted wilt virus (TSWV, genus Tospovirus) $(10,18)$, Tomato yellow leaf curl virus (TYLCV, genus Geminivirus) (7), and Turnip mosaic virus (TuMV, genus Potyvirus) (3). Among these, BYMV, CMV, and TuMV were reported to infect lisianthus in Taiwan $(2,3,5)$.

The objective of this study was to identify the isometric particles associated with the diseased lisianthus. We determined the host range of the virus and examined the symptoms induced by the virus. We also purified the virus and analyzed its properties. The results of this study indicate that this virus is a strain of LNV.

\section{MATERIALS AND METHODS}

Virus source and maintenance. Lisianthus plants with viruslike symptoms were collected in Yung-jing, Changhua, and a virus was isolated from the infected plants by mechanical inoculation in Chenopodium quinoa Willd. Inocula were prepared by grinding infected lisianthus or $C$. quinoa leaves in $0.01 \mathrm{M}$ potassium phosphate (pH 7.0) containing $1 \%$ sodium sulfite. Test plants were grown in an air-conditioned glasshouse and were inoculated by rubbing inoculum on leaves previously dusted with Carborundum.

Host range. Fifty species of plants were mechanically inoculated from infected $C$. quinoa plants and were held in a screen house or growth chamber for 4 weeks for observation of symptom development. Inoculated plants, regardless of symptom development, were then tested by infectivity assay on $C$. quinoa and by enzymelinked immunosorbent assay (ELISA).

Mechanical transmission. We also attempted to dip inoculate artificially wounded roots of healthy lisianthus plants by dipping for $2 \mathrm{~h}$ in inocula prepared from infected C. quinoa. The inoculated plants were potted in sterile noninfested soil and were grown in a screen house for observation.

Insect transmission. Colonies of virusfree Myzus persicae Sulzer and Aphis gossipii Glover were maintained on Cucurbita pepo L. and Nicotiana tabacum L., respectively. Groups of five aphids were transferred to glass tubes and starved for $2 \mathrm{~h}$. They were allowed to feed for $15 \mathrm{~min}$ on infected lisianthus or Nicotiana benthamiana leaves and transferred to healthy lisianthus or $N$. benthamiana plants for a $24-\mathrm{h}$ inoculation feeding period.

Soil transmission. Lisianthus plants bearing viral symptoms along with soil collected from infested fields were planted individually in pots. Two weeks later, three healthy lisianthus seedlings at the five-leaf stage were planted next to the symptombearing diseased plants. Control arrangements were set up using apparently healthy lisianthus and soil collected from adjacent fields where diseased plants were not recorded. They were grown in a screen house and observed daily for symptoms for 4 weeks.

Stability in crude sap. Serial 10-fold dilutions of crude sap in $0.1 \mathrm{M}$ phosphate (pH 7.0) were prepared from infected $C$. quinoa for determination of dilution endpoint of the virus. A 1:10 dilution of crude sap was used to determine the thermal inactivation point and longevity in vitro of the virus. Infectivity was assayed on $C$. quinoa.

Purification. Fresh leaves of $C$. quinoa showing distinct symptoms (numerous local lesions) 2 days after inoculation were 
used as a source for virus purification. The procedure was similar to one previously described (11) except that chloroform and carbon tetrachloride were added during clarification followed by polyethylene glycol $(8 \%)$ and sodium chloride $(0.3 \mathrm{M})$ precipitation.

Electron microscopy. Formvar-coated carbon-stabilized copper grids were floated for 3 min on $15-\mu l$ drops of crude sap extracted from infected lisianthus or C. quinoa or purified virus preparations. Grids were washed with distilled water and stained with $2 \%$ uranyl acetate for $10 \mathrm{~s}$ $(6,22)$. A procedure of immunogold labeling previously described was used to decorate the antigens (14). Formvar-coated carbon-stabilized grids were floated on drops of purified virus suspension and incubated, first with rabbit antisera and then with gold-labeled goat anti-rabbit IgG. They were examined with a JOEL 200CX electron microscope.

Ultrathin sections of leaf tissues of lisianthus and $C$. quinoa showing distinct symptoms were selected and prepared according to a procedure reported (4). They were examined with a JOEL 200CX electron microscope.

Electrophoresis. Purified viruses were disrupted in an equal volume of a protein dissociation buffer $(125 \mathrm{mM}$ Tris- $\mathrm{HCl}$, $20 \%$ glycerol [vol/vol], $10 \%$ 2-mercaptoethanol, $4 \%$ sodium dodecyl sulfate [SDS], and $0.002 \%$ bromophenol blue, $\mathrm{pH} 6.5$ ) by heating in boiling water for $3 \mathrm{~min}$. Protein samples were then electrophoresed in a $10 \%$ polyacrylamide gel in a discontinuous buffer system (13). Protein bands were visualized by Coomassie Blue staining.

Antisera. Rabbits were immunized weekly four times by intramuscular injections of purified virus $(1 \mathrm{mg}$ in $0.5 \mathrm{ml}$ of $0.1 \mathrm{M}$ phosphate, $\mathrm{pH}$ 7.0) emulsified with an equal volume of Freund's complete adjuvant (first injection) or Freund's incomplete adjuvant (the remaining injections). One week after the last injection, rabbits were bled weekly. Titers of antisera were determined by double diffusion test in agar gels. The rabbit antiserum to LNV
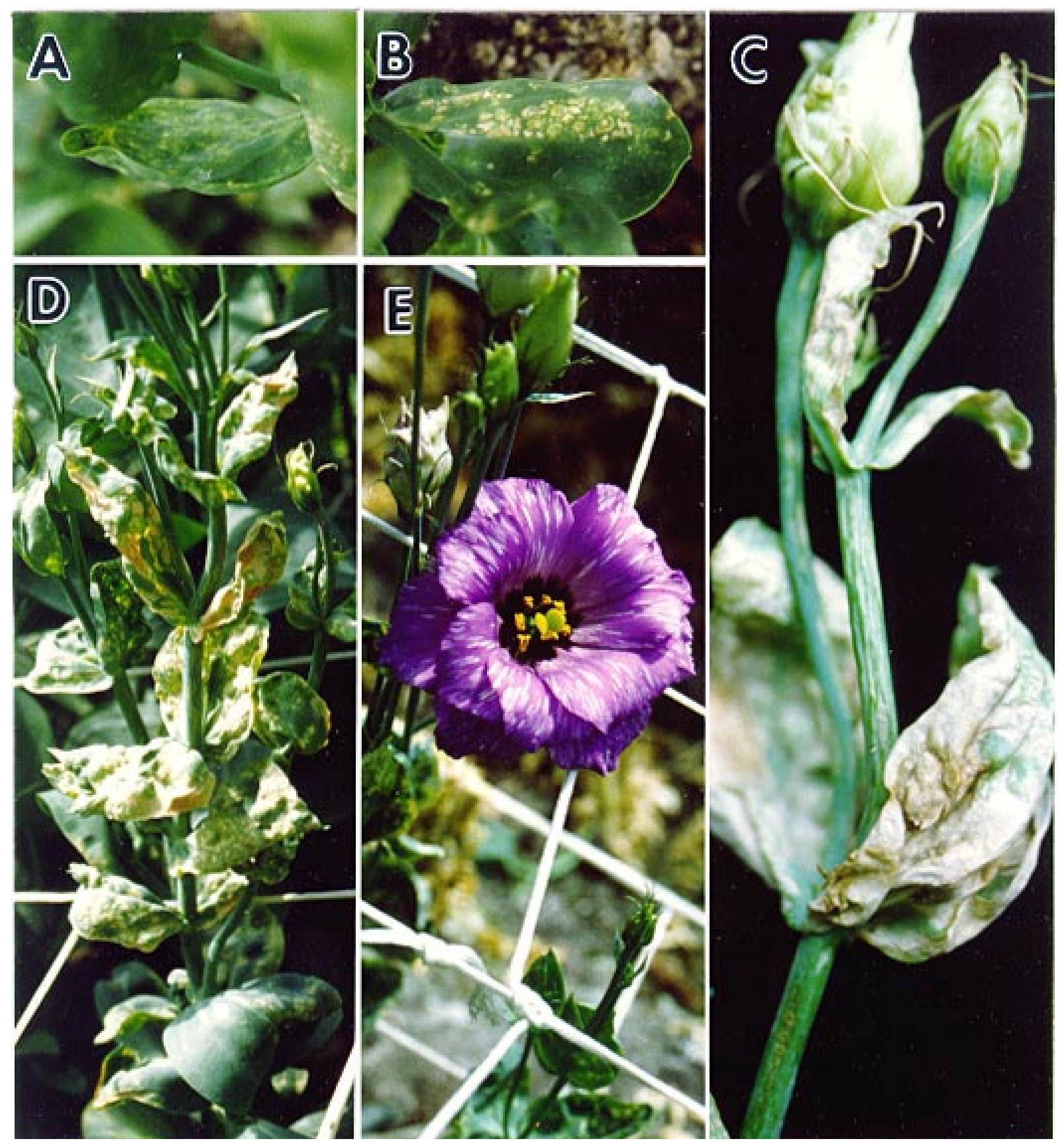

Fig. 1. Leaf symptoms induced by the Taiwan isolate of Lisianthus necrosis virus on Eustoma russellianum include chlorotic spots (A) followed by necrosis (B), which eventually expand and spread to the entire leaf area, leading to death of the plants. Symptoms on stem and peduncle (C) start with chlorotic streaks, which develop into scarred necrotic tissues (D). Flower color breaks (E) are common on diseased lisianthus. 
was a gift from M. Kameya-Iwaki of Yatisera used in the current studies were all incubated with healthy plant materials to remove antibodies that reacted with plant antigens before use in ELISA. An indirect ELISA procedure using alkaline phosphatase-labeled goat anti-rabbit immunoglobulins previously described was used to detect the virus (19).

\section{RESULTS AND DISCUSSION}

Field observation. Diseased plants were first observed among Eustoma hybrids grown in screen houses in Yung-jing, Changhua. These plants were imported in October 1994 as seedlings from Denmark and planted in 16 screen houses with a total area of about 0.4 ha. A grower harvested the first crop of cut flowers the following February and found leaves of some plants with severe necrosis. While the initial time of onset of disease symptoms was uncertain, a survey of all 16 screen houses suggested that the infection was not related to cultivar or flower color. The most severe incidence, with 70 to $80 \%$ infection, appeared in four screen houses on the western side, where the land was lower and the drainage was inadequate. In the houses on the eastern side in the same area, disease incidence was 10 to $40 \%$. In October 1995, seedlings of imported lisianthus were again planted in these screen houses (except for six screen houses toward the east) by the same grower. Necrotic spots began to appear in December on a few plants, again in the western-side screen houses where severe infection had been observed nine months earlier. ELISAs with antisera from Japan confirmed the presence of LNV in diseased plants. So far this virus has been restricted to the nursery of this grower.

Symptoms and host range. Symptoms on naturally infected lisianthus appeared maguchi University, Japan (11). Virus an-

first on the upper leaves as bright yellow chlorotic spots, which gradually became necrotic (Fig. 1A and B). Affected leaves withered and died back (Fig. 1C and D). Foliar symptoms also included necrotic and ring spots in laminae. Similar symptoms were occasionally observed on peduncles and stems (Fig. 1C and D). Faded streaks on petals, malformed or suppressed flowers, and stunting were observed on severely infected plants (Fig. 1E). Lisianthus plants inoculated mechanically or by soil transmission in the laboratory reacted with symptoms similar to those observed on naturally infected plants.

Of the 17 inoculated plant species common to this and other studies, Gomphrena globosa L. developed local lesions on inoculated leaves in the current investigation but showed both local reaction and systemic infection when inoculated with LNV (11). N. tabacum showed both local and systemic reaction to our lisianthus virus but produced only local lesions with LNV (11). Cucumis melo L., C. sativus L., Nicotiana glutinosa L., and Pisum sativum L. were susceptible to LNV inoculation but were not infected with our culture of lisianthus virus. Capsicum annuum L. and Solanum lycopersicum L. var. lycopersicum, on the other hand, were susceptible to lisianthus virus but not to LNV (11). Petunia hybrida Vilm. was susceptible to both viruses. It developed local necrosis on inoculated leaves with lisianthus virus but showed symptomless infection when inoculated with LNV (11). Dianthus caryophyllus L. and D. chinensis L. were not infected with either virus. Chenopodium album L. var. album (Chenopodium amaranticolor Coste \& Reyn), C. quinoa, Cucurbita pepo, Phaseolus vulgaris L., and Zinnia violacea Cav. (Zinnia elegans) all produced only local reactions, whereas E. russellianum also developed systemic infection when inoculated with either virus source.

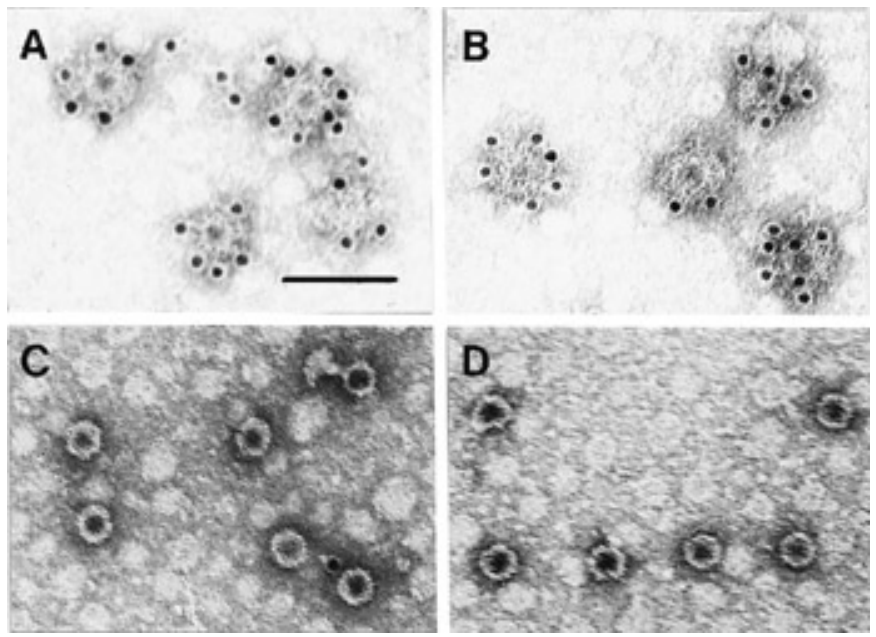

Fig. 2. Gold-labeled immunoelectron microscopy of the Taiwan isolate of Lisianthus necrosis virus (LNV). Purified virions were treated with rabbit antiserum against LNV prepared in current studies (A); rabbit antiserum against whole virions of a Japanese isolate of LNV (B); normal serum (C); and rabbit antiserum prepared to Cucumber mosaic virus (D). The bar represents $100 \mathrm{~nm}$.
Current studies also revealed additional local lesion hosts that were not previously reported. They are Catharanthus roseus L., Celosia argentea L., Cucumis metuliferus E. Mey. ex Naud., Datura stramonium L., Glycine max L., Impatiens walleriana Hook., Mirabilis jalapa L., Nicotiana rustica L., Solanum melongena L., Vigna angularis Willd., V. mungo var. sutrilobota, and $V$. radiata L. Nicotiana benthamiana, however, produced local lesions followed by systemic invasion when inoculated with our lisianthus virus. The following plants failed to develop symptoms when inoculated with crude extracts of leaves of infected lisianthus plants and tested negatively for LNV by ELISA: Amaranthus mangostanus L., A. mangostanus form ruber, A. viridis L., Arachis hypogaea L., Benincasa hispida Thunb., Brassica campestris subsp. chinesis var. communis, $B$. chinensis L., Carica papaya L., Chenopodium ficifolium Sm., Citrullus lanatus Thunb. var. lanatus (Citrullus vulgaris), Dahlia hybrida Hort., Dendranthema $\times$ grandiflorum Kitam. (Chrysanthemum morifolium), Dianthus barbatus L., Gypsophila paniculata L., Helianthus annuus L., Luffa aegyptiaca P. Mill. (Luffa cylindrica Roem.), Mirabilis jalapa L., Rosa hybrida, Solanum nigrum L., and Tagetes erecta $\mathrm{L}$.

Transmission. Both $M$. persicae and $A$. gossypii failed to transmit the virus from diseased lisianthus or $N$. benthamiana to healthy lisianthus $(0 / 10)$ and $N$. benthamiana (0/8), respectively. Results from soil transmission experiments showed that seven of 20 lisianthus plants developed viral symptoms 20 to 25 days after transplanting in pots containing infested soil. Symptoms include necrotic spots on upper leaves. Mechanical inoculation with inocula from either lisianthus or $C$. quinoa resulted in $60 \%$ of more than 300 inoculated plants infected within 5 to 10 days. Inoculation of 61 lisianthus plants by dipping wounded roots in virus solution resulted in $77 \%$ of plants infected in 15 to 23 days.

Soil-borne transmission is a character associated with necroviruses and is due to the presence of fungal vectors Olpidium spp. in the soil (8). Olpidium-like structures were not observed in the rootlets of infected lisianthus. Attempts to isolate Olpidium spp. from a soil suspension were not successful. Results from current studies, however, indicate that the lisianthus virus was able to spread through soil transmission.

The virus. Virus retained infectivity in crude sap at a dilution of $10^{-10}$ but not at $10^{-11}$. Crude virus extracts remained infectious at $20^{\circ} \mathrm{C}$ for 15 days but not beyond 16 days. The virus had a thermal inactivation point between 95 and $100^{\circ} \mathrm{C}$. Purified virus suspension revealed a typical UV absorbance spectrum of nucleoprotein showing a maximum-minimum $\left(A_{260} / A_{240}\right)$ ratio of 1.48 . Purified virus preparations 
contained spherical particles 32 to $33 \mathrm{~nm}$ in diameter, similar to LNV (11). Electrophoretic analysis of SDS-dissociated virus revealed the presence of a single polypeptide with a relative molecular weight of approximately $38 \mathrm{kDa}$ from four determinations.

Leaf dip preparations from infected lisianthus and $C$. quinoa plants contained spherical particles similar to those in purified preparation. Virion particles with similar profiles were frequently observed in ultrathin sections of infected tissues from leaves, stems, roots, and petals. Virions scattered either in irregular clusters or as a regular array in crystalline structures of inclusion bodies in cytoplasm. No virions were found in the nucleus.

Serology. LNV antigens are relatively weak immunogens. Antiserum produced in rabbits in current studies had an immunodiffusion titer of $1 / 8$. It was, however, adequate for use in ELISA and gold-labeling studies in electron microscopy. In ELISA, the antisera prepared in the current investigation and the LNV antiserum obtained from Japan reacted with extracts of leaves of infected lisianthus or $C$. quinoa. The dilution endpoints in lisianthus and $C$. quinoa tested by ELISA were $10^{-6}$ and $10^{-5}$, respectively. Immunogold electron microscopy showed that virions in purified preparations were indeed labeled with gold particles after treatment with antisera produced in the current studies or that obtained from Japan (Fig. 2A and B). Virions were not labeled when treated with normal rabbit serum or antiserum prepared to CMV (Fig. 2C and D).

Among viruses infecting lisianthus, CMV, LLPV, and LNV are distinct species similar in morphology $(9,11,12,17,20)$. The virus isolated from lisianthus in the current studies shares many properties with LNV reported in Japan, including particle profile, manner of transmission, serological reaction, and stability in vitro (11). Differences in host ranges and the reaction to virus infection suggest biological differ- ences within the virus. The lisianthus virus reported in this study may be considered a strain of LNV.

Lisianthus has been grown in Taiwan for many years. Only recently have LNV infections been discovered. Although olpidia were not found, the soil-borne nature of LNV suggests that the original diseased plants may have arrived through the importation of infected seedlings or infested culture matrix associated with the seedlings.

\section{ACKNOWLEDGMENTS}

Supported in part by a study leave grant from the National Science Council of Taiwan (HTH). Plant authorities were obtained from (i) USDA, NRCS 1999, The PLANTS database (http:// plants.usda.gov/plants), National Plant Data Center, Baton Rouge, LA 70874-4490 USA, and (ii) List of Plant Diseases in Taiwan. 1991. Ed. Y. P. Tsai. The Plant Protection Society of the Republic of China and the Phytopathological Society of the Republic of China.

\section{LITERATURE CITED}

1. Brunt, A. A. 1988. New economically important virus and virus-like diseases of ornamental plants. Acta Hortic. 234:505-514.

2. Chang, C. A. 1994. Virus diseases. Pages 2945 in: Proc. Workshop Dis. Diagnosis Floral Crops. Phytopathological Society of the Republic of China.

3. Chao, C. H., Chen, C. C., and Chang, C. A. 1998. Identification of turnip mosaic potyvirus isolated from Lisianthus. (Abstr. in Chinese) Plant Pathol. Bull. 7:223.

4. Chen, C. C., Chen, M. J., Chiu, R. J., and Hsu, H. T. 1989. Morphological comparisons of Echinochloa ragged stunt and rice ragged stunt viruses by electron microscopy. Phytopathology 79:235-241.

5. Chen, C. C., and Hu, C. C. 1999. Purification and characterization of a cucumovirus from Lisianthus russellianum. Plant Prot. Bull. 41:179-198.

6. Christie, S. R., Purcifull, D. E., Crawford, W. E., and Ahmed, N. A. 1987. Electron microscopy of negatively stained clarified viral concentrates obtained from small tissue samples with appendices on negative staining techniques. Fla. Agric. Exp. Stn. Bull. 872.

7. Cohen, J., Gera, A., Ecker, R., Ben Joseph, R., Perlsman, M., Gokkes, M., Lachman, O., and Antignus, Y. 1995. Lisianthus leaf curl, a new disease of lisianthus caused by tomato yellow leaf curl virus. Plant Dis. 79:416-420.

8. Francki, R. I. B., Fauquet, C. M., Knudson, D. L., and Brown, F. 1991. Classification and Nomenclature of Viruses. Springer-Verlag/Wein Press, New York.

9. Gera, A., and Cohen, J. 1990. The natural occurrence of bean yellow mosaic, cucumber mosaic and tobacco mosaic viruses in lisianthus in Israel. Plant Pathol. 39:561-564.

10. Hsu, H. T., and Lawson, R. H. 1991. Direct tissue blotting for detection of tomato spotted wilt virus in Impatiens. Plant Dis. 75:292295.

11. Iwaki, M., Hanada, K., Maria, E. R. A., and Onogi, S. 1987. Lisianthus necrosis virus, a new necrovirus from Eustoma russellianum. Phytopathology 77:867-870.

12. Iwaki, M., Maria, E. R. A., Hanada, K., Onogi, S., and Zenbayashi, R. 1985. Three viruses occurred in lisianthus plants. Ann. Phytopathol. Soc. Jpn. 52:355.

13. Laemmli, U. K. 1970. Cleavage of structural proteins during the assembly of the head of bacteriophage T4. Nature 227:680-685.

14. Lin, N. S. 1984. Gold-IgG complexes improve the detection and identification of viruses in leaf dip preparations. J. Virol. Methods 8:181-190.

15. Lisa, V., and Dellavalle, G. 1987. Bean yellow mosaic virus in Lisianthus russelianum. Plant Pathol. 36:214-215.

16. Lisa, V., and Dellavalle, G. 1989. Malattie da virus del lisianthus. Atti Giorn. Studio. S. O. I. sul lisianthus, Saremo, Italy 1989:85-88.

17. Lisa, V., Vaira, A. M., d'Aquilio, M., Dellavalle, G., Masenga, V., Milne, R. G., and Boccardo, G. 1994. Characterization of an ilarvirus from lisianthus (Eustoma grandiflorum). Acta. Hortic. 377:81-89.

18. Lisa, V., Vaira, A. M., Milne, R. G., Luisoni, E., and Rapetti, S. 1990. Tomato spotted wilt virus in five crops in Liguria. Inform. Fitopatol. 40:34-41.

19. Lommel, S. A., McCain, A. H., and Morris, T. J. 1982. Evaluation of indirect enzyme-linked immunosorbent assay for the detection of plant viruses. Phytopathology 72:1018-1022.

20. Provvidenti, R. 1985. Two newly recognized hosts of cucumber mosaic virus: Eustoma grandiflorum and Peristrophe angustifolia. Plant Dis. 69:542.

21. Roh, M. S. M., and Lawson, R. H. 1984. The lure of lisianthus. Flowers of the Far East capture interest of the West. Greenhouse Manager 2:103-121.

22. Venable, J. H., and Coggeshall, R. 1965. A simplified lead citrate stain for use in electron microscopy. J. Cell Biol. 25:407-408. 